Leszek Sobkowiak

Uniwersytet Wrocławski

\title{
Konflikt polityczny: interdyscyplinarny i wielopłaszczyznowy przedmiot badań
}

DOI: 10.19195/1643-0328.22.1

Słowa kluczowe: konflikt, teorie konfliktu, analiza konfliktu, socjologia, psychologia polityczna, politologia, podejście kratocentryczne, podejście socjocentryczne

\section{Wprowadzenie}

Złożony, skomplikowany charakter konfliktowych relacji międzyludzkich dobrze oddają takie ich aspekty, jak „wrogość, wojna, współzawodnictwo, antagonizm, napięcie, sprzeczność, spory, sprzeczki, niezgodność, kontrowersje, przemoc, opozycja, rewolucja, walka" ${ }^{1}$, kooperacja negatywna, władza, dezintegracja, anomia, różnorodność, polaryzacja, lęk, strach, stres, frustracja, podporządkowanie, dominacja, demoralizacja, dehumanizacja, nienawiść, okrucieństwo itp. Jednocześnie w relacjach stron konfliktu występują przeciwstawne aspekty: współdziałanie, integracja, zgodność, tożsamość, kompromis, porozumienie itd. Jedna z typologii zachowań społecznych wyróżnia agresję, uległość i asertywność, inna - współpracę, walkę i kompromis. Są one przedmiotem badań wielu dyscyplin i subdyscyplin nauki - filozofii, historii, prawa, prakseologii, ekonomii, socjologii, psychologii, politologii, komunikologii, socjotechniki, marketingu itd.

$\mathrm{Z}$ bogatej problematyki konfliktów społecznych i politycznych podejmuję kilka zagadnień mających istotne znaczenie dla perspektywy politologicznej: elementy dorobku socjologii i psychologii politycznej; elementy analizy konfliktów politycznych; przyczynowo-skutkowe mechanizmy konfliktów politycznych.

Procesy rozwoju i instytucjonalizacji nauki o polityce poprzedzone były rozwojem innych nauk humanistycznych i społecznych. Podejmowały one refleksję nad społecznymi, ekonomicznymi, politycznymi i kulturowymi mechanizmami rozwoju społecznego. Badania obejmowały ich aspekty obiektywne i subiektywne, materialne i świadomościowe, podmiotowe, instytucjonalne, behawioralne itp., występujące na różnych poziomach życia społecznego - w skali mikro, mezzo i makro.

${ }^{1}$ J.H. Turner, Struktura teorii socjologicznej, Warszawa 1985, s. 245-246. 
Problematyka konfliktów politycznych nie była i nie jest wyłączną „,własnością” nauki o polityce. W ujęciu chronologicznym dyscyplina ta zaczęła się rozwijać w późniejszym okresie niż socjologia i psychologia. Metodologiczny, teoretyczny i empiryczny dorobek tych dyscyplin ma niewątpliwe znaczenie w wyjaśnianiu konfliktów społecznych i politycznych. Trudno sobie wyobrazić poznawczą i praktyczną przydatność wiedzy o konfliktach — w zakresie funkcji opisowej, wyjaśniającej, prognostycznej i instrumentalnej - bez teoretycznego i empirycznego „wkładu” socjologii i psychologii.

Nie oznacza to deprecjacji dorobku politologii ani zarzutu jego wtórnego charakteru. Podkreślenia wymaga kumulatywny charakter rozwoju wiedzy o człowieku i społeczeństwie. Pola badawcze nauk społecznych nie są rozłącznymi bytami. Konkretne zagadnienia badawcze podejmowane w ramach nauk społecznych, poza typowymi dla danej dyscypliny rezultatami ich konceptualizacji, posiadają także aspekty będące przedmiotem zainteresowania innych dyscyplin. Aspekty te współtworząc dane zjawisko czy proces, są w rzeczywistości niepodzielne, stanowią nierozerwalną całość i jedynie przez zabiegi metodologiczne można wyabstrahować z nich specyficzny dla poszczególnych dyscyplin przedmiot badań.

W rezultacie, nie umniejszając poznawczej wartości badań nad konfliktami prowadzonych wewnątrz danej dyscypliny, ich satysfakcjonujące wyjaśnienie wymaga interdyscyplinarnego i wieloaspektowego podejścia badawczego. W tym ujęciu mieści się np. stanowisko Lecha Zachera, który mówiąc o konfliktach jako mechanizmie zmiany rzeczywistości politycznej, postuluje przyjęcie wielopłaszczyznowego modelu tej rzeczywistości. Autor ten wskazuje cztery powiązane z sobą składniki-modele:

— model polityczny per se (odzwierciedlający głównie relacje władzy); - model ekonomiczny (wyjaśniający gospodarcze zjawiska, procesy, decyzje); — model ideologiczny (obejmujący świat idei, wierzeń religijnych, politycznych deklaracji i programów itp.); - model psychologiczny (behawioralny) - dotyczący ludzkiego zachowania oraz emocji je stymulujących ${ }^{2}$.

\section{Konflikt z perspektywy socjologii}

W socjologii, nauce badającej strukturę i dynamikę społeczeństw, teorie rozwoju społecznego w różny sposób rozstrzygają kwestię roli konfliktów w rozwoju społecznym. Omówienie ukształtowanych na przestrzeni wieków autorskich propozycji w tym zakresie nie jest przedmiotem opracowania. Stąd też odwołuję się jedynie do dwubiegunowego dla jednych, a zarazem komplementarnego dla innych, ujęcia problematyki konfliktów społecznych w teoriach socjologicznych. W intelektualnej, poznawczej rywalizacji między dwiema podstawowymi interpretacjami mechanizmów rozwoju społecznego, tzn. teorią funkcjonalną i teorią konfliktową — nie umniejszając wkładu innych teorii w wyjaśnianie społecznego świata - wskazywane i wartościowane były odmienne czynniki sprawcze, funkcje i uwarunkowania procesów społecznych.

${ }^{2}$ L.W. Zacher, Modelowanie konfliktów - niektóre problemy, [w:] Z zagadnień socjologii polityki, t. 1. Klasyczne i nowe obszary badawcze. Pogranicza dyscyplin i dziedzin. Kwestie teorii i praktyki, red. idem, Lublin 1996, s. 200. 
Pierwotnie teorie tworzone $\mathrm{w}$ ramach podejścia funkcjonalnego ${ }^{3}$ odrzucały bądź pomniejszały znaczenie konfliktu jako kategorii wyjaśniającej oraz rolę konfliktów w rozwoju społecznym, w najlepszym razie przypisując im wtórny - wobec mechanizmów funkcjonalnych, „zgodnościowych” - charakter. Nadrzędnym mechanizmem było natomiast zgodne współdziałanie elementów współtworzących społeczeństwo. W opartej na stanowisku Talcotta Parsonsa, zwięzłej, idealizacyjnej charakterystyce integracyjnej teorii społeczeństwa Ralf Dahrendorf wskazał na względną trwałość, stabilność i integrację społeczeństwa (systemów społecznych) oraz akceptację pewnych wartości przez członków społeczeństwa. Dzięki tym właściwościom społeczeństwa funkcjonują $\mathrm{w}$ dynamicznie rozumianej równowadze, respektując i rozwijając pewien pożądany ład społeczny ${ }^{4}$. W późniejszym czasie przedstawiciele funkcjonalizmu zaczęli traktować konflikt jako istotny mechanizm życia społecznego, pełniący nie tylko, jak wcześniej, „dewiacyjne”, ale także pozytywne dla systemów społecznych funkcje. Krzysztof Tyszka, analizując poglądy Roberta Mertona, podkreślił, że „socjolog musi w równej mierze dostrzegać oba aspekty rzeczywistości społecznej - harmonii i dysharmonii, ładu i konfliktu, trwałości i zmiany"5.

Konfliktowe teorie społeczeństwa ${ }^{6}$ eksponują konflikt jako najważniejszy bądź jeden z najważniejszych mechanizmów rozwoju społecznego. Anthony Giddens stwierdza, że socjologowie reprezentujący to podejście badawcze

podkreślają znaczenie podziałów społecznych, a tym samym kładą nacisk na zagadnienia związane z władzą, nierównościami i walką. [...] społeczeństwo składa się z różnych grup starających się realizować własne interesy. Odmienność tych interesów sprawia, że zawsze istnieje potencjalny konflikt i że pewne grupy mają większe szanse na odniesienie korzyści niż inne. Teoretycy konfliktu badają napięcia między dominującymi i nieuprzywilejowanymi grupami społeczeństwa oraz mechanizmy ustalania i utrzymywania się stosunków dominacji ${ }^{7}$.

Z kolei Dahrendorf - przyjmując nazwę „koercyjna teoria społeczeństwa” - akcentuje: dynamikę $\mathrm{i}$ „,wszechobecne” procesy zmiany społecznej, niezgodność i konflikt interesów między podmiotami, czego konsekwencją jest dezintegracja i zmiany społeczeństwa oraz stosowanie przymusu jako mechanizmu względnej jego trwałości ${ }^{8}$.

Jakkolwiek powyższe orientacje badawcze wyraźnie podkreślały swoisty separatyzm, tzn. odrębność i oryginalność swojego dorobku, to pojawiło się stanowisko uzasadniające ich komplementarny charakter. Znaczącym przykładem są rozległe i głębokie rozważania Jonathana $\mathrm{H}$. Turnera - obejmujące prace klasyków problematyki i zarazem twórców oryginalnych teorii konfliktu, tj. Marksa, Simmla, Cosera i Dahrendorfa - dotyczące m.in. rozbudowanego, dziewięcioelementowego modelu przyczynowego kon-

3 Zob. T. Parsons, System społeczny, Warszawa 2009; J.H. Turner, op. cit., cz. 1; P. Sztompka, Socjologia zmian społecznych, Kraków 2010, rozdział 6 i 7.

${ }^{4}$ R. Dahrendorf, Klasy i konflikt klasowy w społeczeństwie przemysłowym, Kraków 2008, s. 146; L. Sobkowiak, Konflikt polityczny - analiza pojęcia, [w:] Studia z teorii polityki, red. A.W. Jabłoński, L. Sobkowiak, t. 1, Wrocław 1999, s. 117-120.

${ }^{5}$ A.W. Jelonek, K. Tyszka, Koncepcje rozwoju społecznego, Warszawa 2001, s. 26.

${ }^{6}$ J.H. Turner, op. cit., cz. 2.

7 A. Giddens, Socjologia, Warszawa 2007, s. 41.

8 R. Dahrendorf, op. cit., s. 147. 
fliktu ${ }^{9}$ W tym miejscu przytoczę inną propozycję Turnera, w postaci ogólnego modelu procesów przyczynowych, który dobrze oddaje źródła dynamiki rozwoju społecznego: „wszystkie systemy społeczne wykazują nierówności w podziale dóbr, co jest przyczyną konfliktu, który z kolei jest przyczyną reorganizacji systemu społecznego”, a „reorganizacja systemu wywołuje ponownie proces wytwarzający konflikt"10.

Poza metateoretycznym wkładem do wiedzy o konfliktach społecznych, na niższym poziomie ogólności socjologia bada obecne w strukturach społecznych mechanizmy konfliktów - zróżnicowanie interesów, pozycji społecznych, ról społecznych, tożsamości, kultur czy uczestnictwa społecznego. $Z$ politologicznego punktu widzenia istotne są zarówno źródła-przyczyny zróżnicowania społecznego, jak i jego konsekwencje w postaci konfliktowych działań politycznych oraz ich rezultatów, zmieniających (w tym dezintegrujących) struktury społeczne.

\section{Konflikt z perspektywy psychologii}

Wiedza z zakresu psychologii ogólnej i psychologii społecznej stanowi „podłoże” psychologii politycznej. Amerykańscy psychologowie - autorzy cenionego podręcznika uważają, że

na najbardziej ogólnym poziomie psychologia polityczna jest zastosowaniem naszej wiedzy na temat psychologii człowieka do badania polityki. W zakresie psychologii odwołuje się ona do teorii i badań dotyczących osobowości, psychopatologii, psychologii społecznej, rozwojowej, poznawczej oraz relacji międzygrupowych. Jej przedmiotem są zjawiska polityczne, takie jak indywidualna biografia i przywództwo, masowe zachowania polityczne, wpływ komunikacji masowej, socjalizacja polityczna i wychowania obywatelskie, konflikty międzynarodowe, podejmowanie decyzji w polityce zagranicznej, rozwiązywanie konfliktów, konflikty między grupami na podłożu rasowym, płciowym, narodowościowym lub innym, ruchy polityczne i mobilizacja polityczna ${ }^{11}$.

Krystyna Skarżyńska charakteryzując kierunki rozwoju psychologii politycznej, zwraca uwagę na dwa sposoby rozumienia tej subdyscypliny. Można ją ujmować: 1) jako „bezpośrednią aplikację psychologicznych modeli teoretycznych do sfery polityki” oraz 2) jako efekt rozwoju i różnicowania wewnętrznego samej psychologii oraz współpracy psychologii i różnych nauk społecznych. Zainteresowania badawcze tej dyscypliny ewoluowały od osobowościowych uwarunkowań świadomości i zachowań politycznych, przez postawy i zachowania wyborcze, do procesów poznawczych i decyzyjnych, psychologicznego kontekstu transformacji systemowej końca XX w., uwarunkowań (w tym zagrożeń) demokracji. W ostatnich dekadach środowisko polskich psychologów politycznych podejmowało zwłaszcza „studia nad konfliktami politycznymi i sposobami ich rozwiązywania oraz badania nad postawami wobec zmian systemowych", integracji europejskiej, grup narodowych, nad aktywnością i biernością polityczną ${ }^{12}$.

\footnotetext{
9 J.H. Turner, op. cit., rozdział 9, s. 254-255.

10 Ibidem, s. 251.

11 Psychologia polityczna, red. D.O. Sears, L. Huddy, R. Jervis, Kraków 2008, s. 1.

12 K. Skarżyńska, Człowiek a polityka. Zarys psychologii politycznej, Warszawa 2005, s. 13-20.
} 
Psychologia bada konflikt jako specyficzny mechanizm współwyznaczający indywidualne i zbiorowe funkcjonowanie ludzi - członków różnych zbiorowości. Dążąc do wyjaśnienia zachowań, badania zorientowane są - w pewnym uproszczeniu - na procesy psychiczne obecne $\mathrm{w}$ dwóch ogólnych, ściśle powiązanych i faktycznie nierozerwalnych obszarach funkcjonowania jednostek i zbiorowości społecznych: pierwszy to procesy emocjonalne (afektywne), natomiast drugi to procesy poznawcze (intelektualne).

$\mathrm{Z}$ jednej strony, niekwestionowane jest założenie, iż jednym z podstawowych czynników warunkujących właściwości konfliktu (jego genezę, rodzaj, funkcje, przebieg, skutki itp.) jest emocjonalne pobudzenie ludzi. Badaniom podlegają więc właściwości emocji jako takich oraz specyfika emocji towarzyszących konfliktowi - ich rodzaje, wpływ na myślenie i zachowania uczestników konfliktów, mechanizmy pobudzania i eskalacji, natężenie, sposoby przejawiania się itp. $Z$ drugiej strony, przedmiotem badań są intelektualne mechanizmy kształtujące myślenie, osobowość, postawy i zachowania ludzi. Badane są ich aspekty świadome i nieświadome, poznawcze - sposoby i rezultaty postrzegania rzeczywistości społecznej i behawioralne - wzorce zachowań (np. konformistycznych, nonkonformistycznych, socjocentrycznych, egocentrycznych, agresywnych, asertywnych), aksjologiczne, wolicjonalne, ocenne, motywacyjne itp.

W dorobku psychologii znajduje się wiele teorii bezpośrednio bądź pośrednio (warunkując dyspozycje emocjonalne i umysłowe ludzi) wyjaśniających mechanizmy konfliktów społecznych. Przytaczając jedynie kilka teorii, wskażę te ich elementy, które mają konfliktogenne znaczenie:

- realistyczna teoria konfliktów, w której przyczyną konfliktów są sprzeczne interesy, stąd też analiza usytuowania grup społecznych i ich interesów prowadzi do określenia natężenia poczucia zagrożenia w poszczególnych grupach, warunkującego wrogie postawy i zachowania ${ }^{13}$;

- teoria tożsamości społecznej (społecznej kategoryzacji), gdzie ocena elementów rzeczywistości społecznej (ludzi, ich właściwości, zdarzeń, sytuacji itp.) prowadzi do tworzenia ich kategorii w ujęciu: pozytywne-negatywne, lepsze-gorsze, własne-obce, my-oni; podstawą takiej kategoryzacji mogą być obiektywne cechy, fakty czy wskaźniki, ale również subiektywne przekonania; jednocześnie „tendencja do nierealistycznego wywyższania własnej grupy i poniżania grup innych nasila się wtedy, gdy poczucie własnej wartości członków grupy zostaje zagrożone" ${ }^{14}$;

— teoria skryptów afektywnych, wyjaśniająca relacje między „ideologiami a przeżywaniem, wyrażaniem i spostrzeganiem emocji oraz z postawami i zachowaniami w relacjach między ludźmi", różnicująca emocjonalne, intelektualne i behawioralne predyspozycje ludzi w zależności od uznawania ideologii prawicowych bądź lewicowych ${ }^{15}$;

— teoria dogmatyzmu (otwartości-zamkniętości umysłu), wskazująca „na możliwe podobieństwo $\mathrm{w}$ sposobie myślenia osób, które zdecydowanie się różnią treścią akcep-

13 J. Reykowski, Konflikty polityczne, [w:] Podstawy psychologii politycznej, red. K. Skarżyńska, Poznań 2002, s. 172-173; L. Huddy, Tożsamość grupowa a spójność polityczna, [w:] Psychologia..., s. 484-487; J. Duckitt, Uprzedzenia i wrogość miedzy grupami, [w:] Psychologia..., s. 534-536.

14 J. Reykowski, op. cit., s. 215.

15 K. Skarżyńska, op. cit., s. 63-65. 
towanych przekonań"; jedna $\mathrm{z}$ tez dotyczy pozytywnego lub negatywnego stosunku do innych osób i grup, w zależności od tego, czy ich przekonania uznamy za podobne do naszych; konsekwencją stosunku negatywnego będą poczucie zagrożenia, niechęć, nietolerancja, lęk, wrogość, przy czym im wyższe ich natężenie, tym wyższy poziom dogmatyzmu ${ }^{16}$;

- teoria polaryzacji afektywnej, w której dogmatyzm warunkuje dychotomiczne, spolaryzowane myślenie i wartościowanie elementów otoczenia (podmiotów, zjawisk, wydarzeń itd.) jako pozytywnych — „swoich” lub negatywnych — „obcych”; im większe nasilenie emocji w konflikcie, tym mniejsza zdolność do racjonalnego postrzegania, a zarazem tym większa predyspozycja do skrajnie negatywnych zachowań wobec „obcego"-wroga ${ }^{17}$; w tym kontekście trafna jest uwaga George’a E. Marcusa, że emocje mają „zdolność osłabiania suwerennej powagi rozumu”"18, czego dowodem jest irracjonalność zachowań ludzi w wielu konfliktach;

- teoria osobowości autorytarnej, z założeniami o negatywnej naturze ludzi, hierarchiczności społecznego świata - dominacją jednych i podrzędnością innych ludzi, lękiem i zarazem nienawiścią wobec ludzi dominujących, dyspozycją do represyjnych zachowań.

Prezentacja psychologicznych teorii konfliktu ma z racji charakteru opracowania ograniczony charakter. Psychologia oferuje w tym zakresie wiele innych, płodnych poznawczo propozycji, np. osobowości makiawelicznej, opanowywania trwogi, deprywacji, dysonansu poznawczego, konformizmu, frustracji-agresji, reaktancji, czyli przeciwstawiania $\operatorname{się}^{19}$, tłumu $^{20}$.

\section{Konflikt z perspektywy politologii}

Konflikt jest zasadniczą kategorią refleksji politologicznej. Piśmiennictwo politologii oraz pozostałych nauk społecznych zawiera w tym zakresie bogaty dorobek ${ }^{21}$. W kontekście niniejszego opracowania polityka jest procesem wytwarzania, regulowania i rozstrzyga-

16 Ibidem, s. 65-68.

17 Ibidem, s. 68-69; J. Reykowski, Logika walki. Szkice z psychologii konfliktu społecznego w Polsce, Warszawa 1984, s. 57-82; L. Sobkowiak, Konflikt destruktywny jako mechanizm polityki, „Przegląd Historyczno-Politologiczny" IV, 2011, nr 2 (8), s. 91-94.

18 G.E. Marcus, Psychologia emocji i polityki, [w:] Psychologia..., s. 167.

19 Psychologia społeczna, red. E. Aronson, T.D. Wilson, R.M. Akiert, Poznań 1997.

20 G. Le Bon, Psychologia tłumu, Warszawa 1986.

21 Warto przypomnieć część pochodzących sprzed kilku dekad publikacji, które „przecierały” drogę problematyce konfliktów w polskich naukach społecznych: F. Ryszka, Polityka i wojna. Świadomość potoczna a teorie XX wieku, Warszawa 1975; J. Mucha, Konflikt i społeczeństwo. Z problematyki konfliktu społecznego we współczesnych teoriach zachodnich, Warszawa 1978; J. Rudniański, Elementy prakseologicznej teorii walki. Z zagadnień kooperacji negatywnej, Warszawa 1983; H. Białyszewski, Teoretyczne problemy sprzeczności i konfliktów społecznych, Warszawa 1983; P. Pacewicz, Pomiędzy myślą a rzeczywistością. Rewolucja społeczna jako zjawisko psychologiczne, Wrocław 1983; Sprzeczności i konflikty społeczne oraz ich skutki polityczne, red. B. Pasierb, Warszawa 1989. 
nia konfliktów politycznych. Wśród propozycji definiowania konfliktu znajduje się ich rozumienie jako sfery/mechanizmu: zdobywania, sprawowania i tracenia władzy politycznej; wpływania na procesy polityczne - decyzyjne, wykonawcze, mobilizacyjne, korekcyjne, partycypacyjne itp.; specyficznej postaci relacji i oddziaływań jednostek, grup i organizacji, w związku z nierówną dystrybucją dóbr materialnych i niematerialnych.

$\mathrm{Z}$ jednej strony, konflikty są naturalnymi, obiektywnymi wytworami życia społeczno-politycznego, powstającymi jako rezultat splotu czynników, uwarunkowań w danym miejscu i czasie. Są zarazem rezultatami względnie żywiołowych procesów społecznych - jedynie w pewnym, sytuacyjnie określonym stopniu poddających się kontroli ludzi, czego sens leży w sentencji: „rewolucji się nie robi — ona przychodzi sama”.

Jednakże z drugiej strony, konflikty są również rezultatami intencjonalnych, socjotechnicznych działań/strategii zarówno rządzących, jak i rządzonych, podmiotów władzy i podmiotów opozycji, partii politycznych i organizacji pozarządowych, grup formalnych i nieformalnych itp. - jako celowo skonstruowanych instrumentów/metod osiągania celów społecznych, politycznych, ekonomicznych itd. W tym ujęciu konflikt jest świadomie sterowanym procesem osiągania celów przez powodowanie określonych stanów świadomości i zachowań ludzi. Tak więc socjotechniczna regulacja konfliktów może zmierzać do wytworzenia nowego konfliktu (przykłady zarządzania organizacjami przez celowe wprowadzanie konfliktu) i sterowania jego przebiegiem oraz sterowania istniejącymi konfliktami, przez zwiększanie bądź zmniejszanie ich natężenia i zakresu, do rozstrzygnięcia bądź rozwiązania konfliktu włącznie ${ }^{22}$.

Analizę konfliktów politycznych należy zatem sytuować w dwóch definicyjnych perspektywach polityki: kratocentrycznej i socjocentrycznej ${ }^{23}$. Mam oczywiście świadomość rosnącej w środowisku politologów tendencji do zasadnego skądinąd pomniejszania czy wręcz postulatu odchodzenia od kratocentrycznego podejścia w wyjaśnianiu zjawisk i procesów politycznych. Nie zmienia to jednak faktu, że część procesów politycznych, w tym konfliktów, koncentruje się właśnie w sferze zdobywania dominującej względem rywali pozycji, wraz z kompetencjami decyzyjnymi, kontrolnymi itp. jako narzędziami panowania/rządzenia/zarządzania.

Jednakże błędem byłoby pomijanie perspektywy socjocentrycznej. Dobitnym argumentem jest tutaj trwająca kilkadziesiąt lat podmiotowa emancypacja grup czy środowisk upośledzonych wcześniej w dostępie do władzy, dóbr materialnych, prestiżu itd. oraz do realnego wpływu politycznego. Jej wyraźnym potwierdzeniem jest przynajmniej częściowa materializacja idei społeczeństwa obywatelskiego (przede wszystkim w demokratycznych społeczeństwach), rosnące znaczenie i skala „nowej polityki”, polityki protestu czy inaczej niekonwencjonalnej partycypacji politycznej. Mirosław Karwat określa podejście socjocentryczne jako badanie polityki

22 Zob. L. Sobkowiak, Socjotechniczne mechanizmy walki politycznej, [w:] Socjotechnika $w$ polityce wczoraj i dziś, red. A. Kasińska-Metryka, K. Kasowska-Pedrycz, Kielce 2009, s. 77-93.

23 M. Gulczyński, Politologia, Warszawa 2010, s. 228-239; M. Karwat, Podstawy socjotechniki. Dla politologów, polityków i nie tylko, Warszawa 2014, s. 24-26. 
przez pryzmat współzależności (zbieżności, rozbieżności, przeciwstawienia) interesów, poglądów i dążeń wielu grup społecznych i wspólnot ideowych, ich wzajemnych oddziaływań (sojuszy, konfliktów, kompromisów itd.) i układu sił między nimi ${ }^{24}$.

W konsekwencji, geneza i właściwości części konfliktów politycznych nie wiążą się z motywem przejęcia i sprawowania władzy państwowej, chociaż adresatem oczekiwań i żądań są instytucje tej władzy. Jeszcze inne konflikty rodzą się w bezpośrednich relacjach między grupami/segmentami społeczeństwa.

Kolejny aspekt konfliktu, mający istotne znaczenie dla praktyki społecznej, związany jest $\mathrm{z}$ trzema strategiami postępowania, określonymi w teorii gier. Konflikty mogą mieć postać gry o sumie dodatniej, gry o sumie zerowej lub gry o sumie ujemnej - czego konsekwencjami są odpowiednio: uzyskanie przez strony korzyści poprzez kompromisowe rozstrzygnięcie, przy jednoczesnej minimalizacji negatywnych kosztów konfliktu; dążenie do maksymalizacji korzyści przez daną stronę kosztem przeciwnika; dążenie do wyrządzenia jak największej szkody przeciwnikowi, przy akceptacji poniesienia nawet maksymalnych szkód własnych. Pierwsza strategia jest składnikiem konfliktów konstruktywnych, dwie kolejne - konfliktów destruktywnych.

Jedną z charakterystycznych cech nauk społecznych jest wielość definicji danego pojęcia, arbitralność w nadawaniu im wyjaśniającego sensu oraz spory co do ich poprawności. Jest to jedna $\mathrm{z}$ naturalnych konsekwencji pluralizmu teoretyczno-metodologicznego w naukach społecznych. Niezbędne natomiast jest uzasadnienie przyjętej definicji - niesie ona istotne konsekwencje dla określenia pola badawczego, konceptualizacji badań, doboru metod, budowania twierdzeń, teorii itp.

Nie podejmując przeglądu definicji konfliktu, zasygnalizuję dwie ogólne możliwości jego postrzegania: 1) swoiste podejście „faktograficzne”, „behawioralne”, gdzie konflikt ujmowany jest jako obserwowalne w przestrzeni społecznej przeciwstawne działania (aktywność) różnorakich podmiotów; 2) podejście holistyczne, procesualne, w którym badanie konfliktu powinno objąć jego wszelkie składniki (etapy), włącznie z nieobserwowalnymi bezpośrednio procesami psychicznymi/świadomościowymi; chodzi m.in. o deprywację z powodu ograniczonego dostępu do dóbr, kształtowanie się negatywnych emocji, kategoryzację społeczną (tworzenie się podziału my-oni), krystalizację motywów działania, mechanizmy mobilizacyjne itd.

Nawiązując do rozważań o kratocentrycznym i socjocentrycznym ujęciu polityki, przez konflikt rozumiem proces walki dwóch lub więcej podmiotów (np. partii, instytucji państwowych, organizacji pozarządowych, grup społecznych, ruchów politycznych, jednostek) traktujących swoje potrzeby, interesy, wartości i poglądy jako wzajemnie sprzeczne oraz zmierzających do osiągnięcia pożądanych dóbr materialnych i niematerialnych, korzystnego miejsca w strukturze społecznej/politycznej oraz korzystnych relacji z innymi podmiotami. Realizacja tych celów wiedzie przez sprawowanie władzy politycznej i/lub wywieranie wpływu (oddziaływania) na podmioty władzy i/lub na podmioty niewładcze. W zależności od stosowanej strategii (gry o sumie dodatniej, zerowej, ujemnej) rezultatem konfliktu mogą być akceptowalne bądź nieakceptowalne

24 M. Karwat, op. cit., s. 25. 
przez strony: rozmiary udziału w dobrach, pozycja w społecznej/politycznej strukturze, charakter międzypodmiotowych relacji. Konsekwencje konfliktu można także rozpatrywać w innej perspektywie: ograniczenia możliwości działania, zneutralizowania bądź zniszczenia przeciwnika ${ }^{25}$.

\section{Kategorie analityczne nauki o konfliktach}

W literaturze przedmiotu obecne są relacje $\mathrm{z}$ badań nad konfliktami. W badaniach tych, przynoszących idiograficzne bądź nomotetyczne rezultaty, stosowane są różne podejścia metodologiczne, teorie, narzędzia badawcze, siatki pojęciowe itp. Jeden z możliwych sposobów pojęciowego uporządkowania analizy konfliktów obejmuje: podmioty, przyczyny, funkcje, fazy, dynamikę, metody rozstrzygania, rodzaje i uwarunkowania konfliktów. W lakoniczny sposób przedstawiam wybrane, typowe ich elementy, z zastrzeżeniem niewyczerpania złożonej materii konfliktów:

1. Podmioty konfliktów: według kryterium podmiotowego wyróżnia się konflikty intrapersonalne, interpersonalne, międzygrupowe, międzyorganizacyjne i międzynarodowe.

2. Przyczyny konfliktów: nierówności społeczne; sprzeczność interesów, poczucie własnej wartości i różnice światopoglądowe ${ }^{26}$; zróżnicowanie dostępu do władzy i wpływu politycznego, udziału w dystrybucji dóbr materialnych, pozycji w strukturach społecznych i możliwości realizowania wartości uznawanych przez poszczególne podmio$t^{27}$; procesy normatywne (tworzenie kolektywnych nastrojów, mobilizacja lojalności, procesy podejmowania decyzji, procesy negocjacji i targowania się, strukturalne i psychologiczne zaangażowanie) i procesy percepcyjne (tworzenie lustrzanych obrazów, oporność obrazów na sprzeczne informacje, tzn. dysonans poznawczy ${ }^{28}$ ); deprywacja społeczna (absolutna i względna).

3. Funkcje konfliktów: integracja i zmiana systemów społecznych; różnicująca i identyfikacyjna, integracyjna i dezintegracyjna, demaskatorska i maskująca, progresywna i regresywna, pozytywna i negatywna ${ }^{29}$; tworzenie podziałów w społeczeństwie, kształtowanie solidarności grupowych, powodowanie dynamiki rozwoju społecznego ${ }^{30}$; naruszanie i przywracanie równowagi systemu społecznego.

25 Zob. L. Sobkowiak, Konflikt polityczny..., s. 126.

26 J. Reykowski, O psychologicznych mechanizmach konfliktów międzygrupowych, [w:] Kultura, osobowość, polityka, red. P. Chmielewski, T. Krauze, W. Wesołowski, Warszawa 2002, s. 232-243.

27 Zob. L. Sobkowiak, Konflikt polityczny..., s. 127.

${ }^{28}$ H.C. Kelman, R.J. Fisher, Analiza konfliktów i ich rozwiazywanie, [w:] Psychologia..., s. 294-299.

29 J. Sztumski, J. Wódz, Z problematyki konfliktów społecznych i dezorganizacji społecznej, Wrocław 1984, s. 27-33, 40.

${ }^{30}$ H. Białyszewski, op. cit., s. 125. 
4. Fazy konfliktu: utajenie („pojawiają się warunki sprzyjające sporom, ale jeszcze nie zostały one dokładnie określone przez różne strony”), spostrzeganie, odczuwanie, manifestowanie, zakończenie ${ }^{31}$; inicjacja, eskalacja, rozstrzygnięcie.

5. Dynamika konfliktu: kryterium natężenia konfliktu — różne poziomy emocjonalnego pobudzenia i zaangażowania, wraz z różnym poziomem gotowości do ponoszenia negatywnych skutków konfliktu; kryterium gwałtowności konfliktu — poziom radykalizmu stron konfliktu w stosowaniu metod i środków działania: od łagodnych po ostre, od działań konsensualnych i kompromisowych po stosowanie przemocy, w tym środków militarnych ${ }^{32}$.

6. Metody rozstrzygania konfliktów: regulacja w postaci koncyliacji, mediacji, arbitrażu ${ }^{33}$; agresja, asertywność, uległość; rywalizacja, współpraca, kompromis, unikanie, akomodacja; przemoc, potencjalizacja przemocy, negocjacje, mediacje, arbitraż, przeniesienie działań na inną płaszczyznę, zignorowanie przeciwnika, wycofanie się z konfliktu $^{34}$; deliberacja.

7. Rodzaje konfliktów: według kryterium przedmiotowego — społeczne, ekonomiczne, polityczne, kulturowe; konstruktywne i destruktywne; żywiołowe i zaplanowane; interesów; wartości; poznawcze (sprzeczne informacje, wiedza); klasowe; przemysłowe; religijne; uporczywe (długotrwałe, trudno rozstrzygalne).

8. Uwarunkowania konfliktów: obiektywne i subiektywne (racjonalne i pozaracjonalne, percepcja i mispercepcja); systemowe (normatywne i behawioralne), środowiskowe, sytuacyjne, osobowościowe; kulturowe, psychiczne, biologiczne ${ }^{35}$; historyczne i aktualne; lokalne, regionalne, narodowe, międzynarodowe, globalne.

\section{Przyczynowo-skutkowe mechanizmy konfliktów}

W tej części opracowania opiszę zjawiska wpływające na właściwości, dynamikę i skutki współczesnych oraz przyszłych konfliktów politycznych. Zjawiska te mają zwykle wysoki potencjał konfliktotwórczy albo już wywołały realne konflikty. Występują we wszystkich sferach życia społecznego, w różnych środowiskach, grupach, społeczeństwach i państwach, włącznie z społeczeństwem/systemem globalnym. Bezpośrednio bądź pośrednio współtworzą swego rodzaju system naczyń połączonych, generując nowe czy eskalując wcześniejsze konflikty, uruchamiając pewne sekwencje przyczynowo-skutkowe, czego przykładem są:

- Lokalne konflikty dezintegrujące dane społeczeństwo/państwo i prowadzące do wewnętrznego konfliktu zbrojnego, który przekształca się w wojnę domową powodującą a) interwencję zbrojną innego państwa/państw, b) masową migrację ludności cywilnej,

${ }^{31}$ K. Skarżyńska, op. cit., s. 259-260.

32 R. Dahrendorf, op. cit., s. 187-189.

33 Ibidem, s. 197-203.

34 L. Sobkowiak, Konflikt polityczny..., s. 126; zob. także: S. Chełpa, T. Witkowski, Psychologia konfliktów, Wrocław 1999.

${ }^{35}$ Ibidem, s. 120-123. 
co z kolei wywołuje c) rozlewanie się konfliktu zbrojnego na sąsiednie terytoria i d) kolejną falę migracji, $\mathrm{w}$ efekcie czego następuje e) różnicowanie się i krystalizacja postaw w społeczeństwach przyjmujących lub mających przyjąć migrantów, a postawy te mogą f) uruchomić oddolne zachowania konfliktowe, albo też g) stać się obiektem oddziaływań liderów politycznych, mobilizujących do działań konfliktowych zwolenników/przeciwników migrantów.

- Działalność, opartych zwykle na wartościach religijnych/ideologicznych, radykalnych ruchów i organizacji, posługujących się metodą terroryzmu bądź prowadzących regularne działania militarne na pewnym terytorium, powoduje powstawanie tamże kolejnych konfliktów i/lub nowych konfliktów przez przeniesienie ich aktywności na inne terytoria, co z kolei różnicuje lub polaryzuje postawy, wzajemne relacje, cele i działania funkcjonujących tam podmiotów wobec agresora (przykład pozytywnych, ambiwalentnych i negatywnych reakcji „miejscowych” podmiotów wobec tzw. eksportu rewolucji/wojny).

- Rosnące od kilku dekad w siłę ruchy i organizacje rozpowszechniające nacjonalistyczne, populistyczne itp. ideologie/systemy wartości redefiniują czy po prostu negują humanistyczną, oświeceniową, demokratyczną aksjologię, co powoduje a) przyrost i aksjologiczną konsolidację oraz b) radykalizację werbalnej aktywności ich zwolenników, a reakcją na ten proces może być a) przyrost i aksjologiczna konsolidacja oraz b) radykalizacja werbalnej aktywności ich przeciwników, natomiast końcowym skutkiem będzie aksjologiczna polaryzacja zbiorowości/społeczeństwa, mogąca przyjąć postać werbalnej „wojny” ideologicznej/religijnej.

- Demokratyczna transformacja państw Europy Środkowej i Wschodniej z przełomu lat 80. i 90. XX w., która zmieniła pole wcześniejszych konfliktów, i zarazem (zgodnie z przyczynowym modelem Turnera) reorganizacja systemów były początkiem kolejnych konfliktów. W podmiotowej i przedmiotowej sferze władzy politycznej wyjściowy konflikt „starych”-,,komunistycznych” i "nowych”-,demokratycznych”-"antykomunistycznych" elit politycznych stopniowo tracił swoją dynamikę, zasięg i zakres. Źródłem nowych konfliktów stało się postępujące różnicowanie i ostatecznie ostre wewnętrzne podziały polityczne zwycięskiej strony. Konflikty te „karmiły się” różnymi kwestiami od wizji i strategii konstruowania nowego systemu społecznego w jego ekonomicznym, politycznym, kulturowym itd. wymiarze, przez różnice stanowisk w postaci celów, metod i środków taktycznych i operacyjnych, po decyzje/,politykę” kadrową oraz animozje, wrogość w bezpośrednich relacjach publicznych i osobistych. Ten strukturalny konflikt rodził w kolejnych latach następne konflikty. Ich przykładem jest arena wyborcza, gdzie pozytywnie wartościowane pojęcie rywalizacji o władzę straciło swój etyczny sens. Właściwości praktycznych działań przynajmniej części uczestników procesu wyborczego można określić jako bezwzględną, destruktywną walkę. Konsekwencje powyższych procesów konfliktowych są wielorakie - to nie tylko brutalizacja życia politycznego, spustoszenie w sferze wartości humanistycznych i demokratycznych, wrogość, nienawiść w relacjach międzyludzkich itd.; konsekwencją bodaj najgroźniejszą dla budowania i przetrwania nowych systemów demokratycznych jest dochodzenie do władzy ugrupo- 
wań instrumentalnie traktujących bądź jawnie odrzucających wartości i zasady demokracji. Jedna $z$ ich strategii zawiera cele i działania dotyczące centralizacji i koncentracji władzy politycznej przez modyfikację/osłabienie/destrukcję zasad, norm prawnych i instytucji wypełniających sens pojęć trójpodziału władzy, praworządności, społeczeństwa obywatelskiego, praw obywatelskich itp. Takie strategie wykorzystują istniejące oraz generują nowe konflikty jako metody osiągania celów. Mechanizm sprzężenia zwrotnego jest kolejnym składnikiem/etapem tego swoistego konfliktowego perpetuum mobile.

- Era rewolucji informatyczno-informacyjnej, która uzupełniła, a zarazem zmieniła mechanizmy tradycyjnej komunikacji społecznej — powszechnie dostępne internetowe kanały komunikacyjne cechują się m.in. błyskawicznym przekazywaniem i masowym rozpowszechnianiem prawdy i postprawdy o kimkolwiek i czymkolwiek, dużym stopniem anonimowości nadawców i odbiorców, wysokim poziomem agresji internautów (przykład hejtu), nikłą, mało skuteczną kontrolą treści przez instytucje państwa (przykład Deep Web). Nowe komunikacyjne mechanizmy skutecznie pełnią - obok „zgodnościowych” - konfliktowe funkcje. W części procesu zwanego Arabską Wiosną (pomijam tutaj jej strukturalne i systemowe przyczyny), zwłaszcza w jego inicjalnej i wzrostowej fazie, wykorzystane zostały informacyjne i mobilizacyjne możliwości Internetu. Rozpowszechniane, oprócz innych mediów, przez Internet informacje o negatywnych skutkach działań rządów, wojska, policji czy służb specjalnych kształtowały i potęgowały negatywne postawy rosnącej liczby obywateli. W kolejnych komunikatach zwiększał się udział apeli mobilizacyjnych, skłaniających ludzi do czynnego przeciwstawienia się rządzącym (podobne funkcje informacyjne i mobilizacyjne można było obserwować w protestach przeciw ACTA). Stopniowo w kolejnych państwach wybuchały i rozlewały się protesty $\mathrm{w}$ formie oddolnej, żywiołowej, niekonwencjonalnej partycypacji politycznej, zarówno o pokojowym, jak i militarnym charakterze.

- Działania zwycięzców Arabskiej Wiosny po obaleniu dotychczas rządzących elit, które można ująć jako kilka synchronicznie bądź diachronicznie przebiegających procesów: wyłanianie nowych grup/koalicji rządzących w drodze przetargów, konsensusu, wyborów bądź ostrej walki - po pewnym czasie następowała stabilizacja sytuacji wewnętrznej lub jej destabilizacja skutkująca rozpadem grup rządzących i rosnącą dezintegracją ich zwolenników. W konsekwencji jakieś ugrupowanie próbowało przejąć bądź przejmowało władzę, czego jednym z warunków było ograniczenie/zneutralizowanie dotychczasowych sprzymierzeńców, co w następstwie pogłębiało dezintegrację i osłabiało cały obóz zwycięzców. Niekiedy efektem tego etapu była prowadzona środkami politycznymi i militarnymi walka „wszystkich ze wszystkimi”, co prowadziło do faktycznej erozji władzy centralnej, rozpadu terytorium państwa na domeny różnych ugrupowań polityczno-militarnych itd. W rezultacie dochodziło do kończących się powodzeniem kontrdziałań zwolenników elit obalonych na początku fali protestów, co rozpoczynało kolejną fazę konfliktu. 


\section{Podsumowanie}

Socjologiczne, psychologiczne oraz politologiczne kategorie i teorie konfliktów, opisujące i wyjaśniające ich właściwości, czynią to na różnych poziomach rzeczywistości społeczno-politycznej: od metateorii (jak funkcjonalna i koercyjna) po teorie dotyczące procesów psychicznych. Powinnością nauk społecznych jest badanie konfliktów politycznych w perspektywach: systemów społecznych cechujących się nierównością w dostępie do cenionych dóbr materialnych i symbolicznych; procesów poznawczych, emocjonalnych i motywacyjnych ludzi uczestniczących w konfliktach; wzorców i faktycznych zachowań w warunkach konfliktu; mechanizmów dynamiki konfliktów w postaci związków przyczynowo-skutkowych, które warunkują fazy ich rozwoju; funkcji konfliktów, z ich konstruktywnymi i destruktywnymi skutkami dla jednostek, grup, społeczeństw i społeczeństwa globalnego; integratywnych metod rozstrzygania konfliktów jako elementu strategii gry o sumie dodatniej; wreszcie, kształtowania instytucji systemu społecznego zdolnych do „cywilizowania” konfliktów, przez ograniczanie ich destruktywnych źródeł, metod i skutków.

\section{Bibliografia}

Białyszewski H., Teoretyczne problemy sprzeczności i konfliktów społecznych, Państwowe Wydawnictwo Naukowe, Warszawa 1983.

Chełpa S., Witkowski T., Psychologia konfliktów. Sposoby radzenia sobie ze sporami, Oficyna Wydawnicza Unus, Wrocław 1999.

Dahrendorf R., Klasy i konflikt klasowy w społeczeństwie przemysłowym, Zakład Wydawniczy „Nomos”, Kraków 2008.

Duckitt J., Uprzedzenia i wrogość między grupami, [w:] Psychologia polityczna, red. D.O. Sears, L. Huddy, R. Jervis, Wydawnictwo Uniwersytetu Jagiellońskiego, Kraków 2008.

Giddens A., Socjologia, Wydawnictwo Naukowe PWN, Warszawa 2007.

Gulczyński M., Politologia, AlmaMer, Wyższa Szkoła Ekonomiczna, Warszawa 2010.

Huddy L., Tożsamość grupowa a spójność polityczna, [w:] Psychologia polityczna, red. D.O. Sears, L. Huddy, R. Jervis, Wydawnictwo Uniwersytetu Jagiellońskiego, Kraków 2008.

Jelonek A.W., Tyszka K., Koncepcje rozwoju społecznego, Wydawnictwo Naukowe Scholar, Warszawa 2001. Le Bon G., Psychologia tłumu, Państwowe Wydawnictwo Naukowe, Warszawa 1986.

Karwat M., Podstawy socjotechniki. Dla politologów, polityków i nie tylko, Difin SA, Warszawa 2014.

Kelman H.C., Fisher R.J., Analiza konfliktów i ich rozwiązywanie, [w:] Psychologia polityczna, red. D.O. Sears, L. Huddy, R. Jervis, Wydawnictwo Uniwersytetu Jagiellońskiego, Kraków 2008.

Marcus G.E., Psychologia emocji i polityki, [w:] Psychologia polityczna, red. D.O. Sears, L. Huddy, R. Jervis, Wydawnictwo Uniwersytetu Jagiellońskiego, Kraków 2008.

Mucha J., Konflikt i społeczeństwo. Z problematyki konfliktu społecznego we współczesnych teoriach zachodnich, Państwowe Wydawnictwo Naukowe, Warszawa 1978.

Pacewicz P., Pomiędzy myśla a rzeczywistością. Rewolucja społeczna jako zjawisko psychologiczne, Zakład Narodowy im. Ossolińskich, Wrocław 1983.

Parsons T., System społeczny, Zakład Wydawniczy „Nomos”, Warszawa 2009.

Psychologia polityczna, red. D.O. Sears, L. Huddy, R. Jervis, Wydawnictwo Uniwersytetu Jagiellońskiego, Kraków 2008. 
Psychologia społeczna, red. E. Aronson, T.D. Wilson, R.M. Akiert, Wydawnictwo Zysk i S-ka, Poznań 1997. Reykowski J., Konflikty polityczne, [w:] Podstawy psychologii politycznej, red. K. Skarżyńska, Wydawnictwo Zysk i S-ka, Poznań 2002.

Reykowski J., Logika walki. Szkice z psychologii konfliktu społecznego w Polsce, Książka i Wiedza, Warszawa 1984.

Reykowski J., O psychologicznych mechanizmach konfliktów międzygrupowych, [w:] Kultura, osobowość, polityka, red. P. Chmielewski, T. Krauze, W. Wesołowski, Wydawnictwo Naukowe Scholar, Warszawa 2002.

Rudniański J., Elementy prakseologicznej teorii walki. Z zagadnień kooperacji negatywnej, Państwowe Wydawnictwo Naukowe, Warszawa 1983.

Ryszka F., Polityka i wojna. Świadomość potoczna a teorie XX wieku, Państwowy Instytutu Wydawniczy, Warszawa 1975.

Skarżyńska K., Człowiek a polityka. Zarys psychologii politycznej, Wydawnictwo Naukowe Scholar, Warszawa 2005.

Sobkowiak L., Konflikt destruktywny jako mechanizm polityki, „Przegląd Historyczno-Politologiczny” IV, 2011, nr 2 (8).

Sobkowiak L., Konflikt polityczny - analiza pojęcia, [w:] Studia z teorii polityki, red. A.W. Jabłoński, L. Sobkowiak, t. 1, Wydawnictwo Uniwersytetu Wrocławskiego, Wrocław 1999.

Sobkowiak L., Socjotechniczne mechanizmy walki politycznej, [w:] Socjotechnika w polityce - wczoraj i dziś, red. A. Kasińska-Metryka, K. Kasowska-Pedrycz, Wydawnictwo Uniwersytetu Humanistyczno-Przyrodniczego Jana Kochanowskiego, Kielce 2009.

Sprzeczności i konflikty społeczne oraz ich skutki polityczne, red. B. Pasierb, Państwowe Wydawnictwo Naukowe, Warszawa 1989.

Sztompka P., Socjologia zmian społecznych, Wydawnictwo Znak, Kraków 2010.

Sztumski J., Wódz J., Z problematyki konfliktów społecznych i dezorganizacji społecznej, Ossolineum, Wrocław 1984.

Turner J.H., Struktura teorii socjologicznej, PWN, Warszawa 1985.

Zacher L.W., Modelowanie konfliktów - niektóre problemy, [w:] Z zagadnień socjologii polityki, t. 1. Klasyczne i nowe obszary badawcze. Pogranicza dyscyplin i dziedzin. Kwestie teorii i praktyki, red. idem, Wydawnictwo Uniwersytetu Marii Curie-Skłodowskiej, Lublin 1996.

\section{Political conflict: interdisciplinary and multi-faceted subject matter}

Keywords: conflict, conflict theories, conflict analysis, sociology, political psychology, political science, kratocentric approach, sociocentric approach

Summary

Categories and theories that describe and explain conflicts and their properties, which derive from sociology, psychology and political science, use different levels of social-political reality: from meta-theories (for example functional and coercive) to theories concerning psychological processes. The aim of social sciences is to study political conflict in the following perspectives: social systems featured by unequal access to valued symbolic and material goods; cognitive, emotional and motivational processes of people participating in conflicts; patterns and actual behaviors in conflict situations; mechanisms of conflict dynamics - cause-and-effect relationships that determine phases of conflict development; functions of conflicts, their creative and destructive effects on individuals, groups, societies and global society; integrative methods of conflict-solving as an element of positive sum game strategy; and at last, shaping the institutions of social systems capable of „civilizing” conflicts through limitation of their destructive sources, methods and effects. 